\title{
ONLINE TEAGHING PRAGTICES AND THE EFFECTIVENESS OF THE EDUCATIONAL PROCESS IN THE WAKE OF THE COVID-19 PANDEMIC
}

\author{
Cristina Venera Tartavulea ${ }^{1 *}$, Catalin Nicolae Albu ${ }^{2}$, Nadia Albu $^{3}$, \\ Ramona Iulia Dieaconescu ${ }^{4}$ and Silvia Petre ${ }^{5}$ \\ ${ }^{122334) 5)}$ The Bucharest University of Economic Studies, Romania
}

Please cite this article as:

Tartavulea, C.V., Albu, C.N., Albu, N, Dieaconescu, R.I. and Petre, S., 2020. Online Teaching Practices and the Effectiveness of the Educational Process in the Wake of the COVID-19 Pandemic. Amfiteatru Economic, 22(55), pp. $920-936$.
Article History:

Received: 29 March 2020

Revised: 18 May 2020

Accepted: 29 June 2020

DOI: $10.24818 / \mathrm{EA} / 2020 / 55 / 920$

\begin{abstract}
In this paper, we investigate the impact of the abrupt switch to online teaching which occurred in 2020 due to the COVID-19 pandemic. By using responses from 362 professors and students from 13 European countries, we find that universities and students were very quick to adapt to the new changes and that a mix of synchronous and asynchronous interaction and assessment methods are currently employed. However, this mix is quite limited relative to what is usually subsumed into online learning tools, and is indicative of passive delivery and reduced interaction. Our respondents estimate that most online interaction and assessment methods will continue to be used after the return to face-to-face education. Our respondents also view the switch to online teaching to have an overall moderate positive impact on the educational process, albeit the overall effectiveness of the online educational experience is perceived to be lower than in the case of face-to-face teaching. Moreover, we find that the institutional support, the trust in the online system and the perceived effectiveness of formative assessment are factors that are positively associated with the impact and effectiveness of online education.
\end{abstract}

Keywords: online teaching, quality of online education, effective online education, online instructional methods, online assessment methods

JEL Classification: A23, I23

* Corresponding author, Cristina Venera Tartavulea - cristina.tartavulea@ cig.ase.ro 


\section{Introduction}

Recent developments have prompted universities around the world to shift towards online education, and evolutions in information and communication technology (ICT) have contributed to the emergence of new and innovative education methods for students (Albăstroiu, Felea and Vasiliu, 2014; Kauppi, et al., 2020). E-learning provides easier access to learning, promotes flexibility so that students can overcome space and time limitations and offers new potential for the teaching process to be focused on the learners' needs and possibilities, emphasizing different learning styles (Bonk and Graham, 2006; Onete, et al., 2014; Huang, et al., 2020). However, it was estimated that in 2018 only about $15 \%$ of the market share belonged to online education (Burquel and Busch, 2020). In this context, the 2020 COVID-19 crisis has significantly accelerated the move toward the online environment, on an "untested and unprecedented scale" (Burgess and Sievertsen, 2020). To date, measures of social distancing and school closing impacted the educational system around the world, and tremendous effort was put in over a very short period of time (Bao, 2020; Lim, 2020; QS, 2020).

While there is an increased interest in understanding how universities responded to the pandemic (Bao, 2020; Greene, 2020; Lim, 2020; QS, 2020), there are few studies reflecting on the abrupt switch to online teaching and the significant impact on society and the educational processes is currently not yet fully understood (Burgess and Sievertsen, 2020). In China, the first country which was severely affected by the COVID-19 outbreak, the decision to close universities but continue the process of teaching and learning led to a massive shift to online courses, supported by the government through the initiative called "Disrupted Classes, Undisrupted Learning" (Huang, et al., 2020). In Singapore, a unified approach at university level helped ease the transition to online learning, by ensuring that the educational process continues with similar quality standards, by providing adequate technologies to instructors and students and by putting a strong emphasis on the learners and their needs (Lim, 2020). In Europe, the European Commission (2020) emphasizes that "COVID-19 is reviving the need to explore online teaching and learning opportunities".

We intend to contribute to this debate and to look in more depth at the situation currently affecting extensively the educational system worldwide. Our study investigates how the switch to online education impacted the use of instructional and formative assessment methods and the overall impact and effectiveness of the education process in several European countries. To this end, we statistically analyse responses provided by 114 academics and 248 students from 13 European countries. We focus our analysis on the online educational practices, their causes and consequences, relative to: (1) the means of interaction and student assessment methods employed for online teaching; (2) the barriers to and facilitators of online education; and (3) the effectiveness of online education. We continue the paper by reviewing the relevant literature on the three topics investigated. We then present our methodology, followed by a discussion of our results. The final section outlines the paper's conclusions, implications and future research directions.

\section{Review of the scientific literature}

\subsection{Means of interaction and student assessment in an online educational system}

The nature of the teaching and learning processes changes with the use of e-technologies (Teo, 2011). Most online programs are based on constructivist learning models, which 
presume that learners are actively involved in the educational process by developing meaningful learning experiences and interacting with teachers and peers to accumulate and create knowledge (Bangert, 2006). Multiple instructional methods needs to be used to increase the effectiveness of the online educational process (Dixson, 2010) and compensate for the lack of physical presence of both teachers and students in the same space and time.

Asynchronous and synchronous communication means can be used in the online environment (Kearns, 2012). Asynchronous communication allows the transmission of messages which can be viewed and responded to at any moment of time, as per the participant's convenience. Such means of interaction comprise emails, chat lists, discussion forum/boards, blogs, announcements, shared documents, virtual board, video tutorials and instant messaging (Craig, et al., 2012; Kearns, 2012). Synchronous communication takes place in real time and participants must be logged online at the same time. Such interaction includes text chats, sharing applications, audioconferences and videoconference (Huang, et al., 2020).

The review of the literature indicates therefore that the type of interaction method is important, but also their variety. The purpose of these methods should be to encourage dialogue and interaction between teachers and students (Gaytan and McEwen, 2007), as these are associated with better results of the learning process (Bennett, Lockyer and Agostinho, 2018). Students should be motivated to learn, challenged to think and deploy active learning, offered additional help and provided with varied and meaningful assignments. Additionally, the interaction between students must be encouraged by proposing collaborative/interactive activities that give them the opportunity to share knowledge and experiences, thus building a sense of community (Johnson and Aragon, 2003; Dixson, 2010)

Assessments are also a very important part of the educational process. There are many challenges related to finding effective techniques in the online environment (Liang and Creasy, 2004), as online assessment requires a more ongoing systematic approach than traditional ones (Robles and Braathen, 2002). Online assessment techniques are effective if realistic scenarios are used in setting learning objectives, differences in learning styles are considered, and students receive adequate support in learning activities and using software (Boyle, et al., 2003). Several types of assessments are indicated as effective in the online environment: exams, timed tests/quizzes, self-tests, weekly review questions, homework/written assignments/field work, case study responses, peer evaluation with feedback, projects, short essays, group work, presentations, e-portfolios, rubrics for evaluation of posts \& involvement in discussion forums and reviewing comments in online chats (Robles and Braathen, 2002; Gaytan and McEwen, 2007; Kearns, 2012; Huang, et al., 2020). Another key point in the effectiveness of an online course is that assessments should be consistent with learning activities. The most important learning outcomes that should be tested in online assessments are critical thinking, course knowledge, problem solving, teamwork and communication (OECD, 2013). Assessments should be both formative (i.e., monitor the student's learning progress over the entire course duration) and summative (i.e., evaluate the knowledge and skills acquired by students at the end of the course). In conclusion, prior literature underlines that to be effective, online education needs to be based on a strong methodology, and good teacher-student and student-student interaction (Maki and Maki, 2007). 


\subsection{Barriers to, and facilitators of, online education}

Barriers encountered in the online educational process can come from both internal and external sources and related to students, teachers and schools (Borup and Evmenova, 2019). Technical and ICT-related problems such as insufficient hardware, inappropriate software or their poor management, when existing, have been documented as negatively impacting the use of technology in class (Pelgrum, 2001). These infrastructure-related barriers may be even more difficult to surpass in the current pandemic context (Bao, 2020).

The lack of proper training for both schools and teachers was also identified as a barrier in the ICT uptake, as it is oftentimes overlooked because it is significantly costly (Pelgrum, 2001). Instructors may feel uncomfortable to teach remotely, especially if other factors add up to the lack of training, such as limited technology available at home, insufficient equipment at school, or technical problems faced in technology-assisted teaching. Teachers also face internal barriers including computer anxiety, fear of technology and sometimes badly-defined roles, as they sometime consider their role is just to teach and view the ICT component as something separate, simply adding to their daily tasks and overloading an already saturated schedule (Bhati, et al., 2009).

In their turn, students may experience isolation feelings, which may impact their confidence level in the online learning (de Metz and Bezuidenhout, 2018) and that interferes with their sense of belongingness. The students' sense of isolation may also affect how disciplined they are during the online training period, how many of them actually "complete their degrees compares to their on-campus peers" (Myring, Bott and Edwards, 2014, p. 7) and how much they are likely to participate and truly engage in online learning (de Metz and Bezuidenhout, 2018). Concurrently, in a non-traditional educational setting, students need to be more responsible, have a more efficient time management and higher motivation levels (Grabinski, Kedzior and Krasodomska, 2015; D’Aquila, Wang and Mattia, 2019). Students' abilities regarding the use of internet and mobile devices make them "digital natives", who appreciate the flexibility and efficiency these technologies provide, while at the same time being aware of the increasing importance of the IT skills in the accounting profession, for example (Stanciu and Tinca, 2014; Stanciu and Gheorghe, 2017). Yet, literature points to the need for appropriate teacher support and training (Janse van Rensburg, 2018).

Instructional technology (such as interactive collaboration) should be used to increase the students' engagement (Shi, 2019), especially since the lack of participation is a challenge to overcome by the e-tutors (de Metz and Bezuidenhout, 2018). Since a time gap in interaction is suggested as one of the barriers to online/blended learning, especially in the case of asynchronous modes, research suggests that timely response and feedback are very important for students engaged in distance education (Grabinski, Kedzior and Krasodomska, 2015; Janse van Rensburg, 2018; Martin, Wang and Sadaf, 2018).

Concurrently, in the current crisis context, OECD (2020) recommends schools to improve communication at all institutional levels, to ensure proper support for teachers and vulnerable students, to have a continuity plan and to remain flexible in terms of distance education strategy. However, few studies investigate empirically how these principles are implemented. For example, in a study based in China during the current outbreak, Bao (2020) identifies the lack of experience in teaching online and relevant materials to support it (audio and video recorded content), the short period available for preparation and the 
insufficient support from educational technology staff as the main challenges to switching to online teaching. Despite the identified barriers and difficulties, the transition to online teaching may be an opportunity for higher education institutions to position themselves as experts and knowledge providers in society (Burquel and Busch, 2020), to reinvent themselves and change perspective (Dennis, 2020) and to question the existing bureaucracy (Jones, 2020).

\subsection{Effectiveness of online education}

Many of the articles reviewed on the topic of effective learning refer to the seven principles stated by Chickering and Gamson (1987): (1) Facilitating contact between student and faculty academic and non-academic staff; (2) Encouraging collaboration between students; (3) Encouraging student engagement and active learning; (4) Giving meaningful and timely feedback; (5) Emphasizing time on task; (6) Communicating high expectations and (7) Respecting diverse talents and ways of learning (Gorsky and Blau, 2009). These principles hold in the context of online education as well, and much of the discussion around the quality of the online education process revolve around these performance criteria.

Making the online educational process as effective as possible could be beneficial for both students and educational institutions, since students of online programs can overachieve and outperform on-campus students (Connolly, et al., 2007). For example, a study conducted by McCarthy, Kusaila and Grasso (2019) on accounting education, regarding the impact of online, blended and face-to-face learning, finds that (1) none of them is superior to the others and (2) both accounting and auditing students studying in online and hybrid setups outperformed students from face-to-face and hybrid and face-to-face modes, respectively.

A student-centred educational approach is an important factor in the learners' satisfaction and for the successful integration of ICT instruments when using online technologies (Englund, Olofsson and Price, 2017). As such, teachers may use various approaches to facilitate the technology-mediated education, such as encouraging interaction and collaboration, ensuring that students have a wide pool of activities as well as setting clear deadlines and benefiting from structured courses and increased instructor presence (Warren, et al., 2014), which may prove useful when teaching switches back to a face-toface setup (Baran, Correia, and Thompson, 2013).

To conclude, the forced switch to online teaching caused by the current COVID-19 pandemic caused disruptions in the educational process in universities around the world (Bao, 2020; Greene, 2020; QS, 2020), which might have affected the effectiveness of the educational system. We are concerned with the view European professors and students hold of the advent of online teaching/learning technologies, in the wake of the COVID-19 pandemic. We will turn next to the methodology we have employed for the purpose of our study, followed by the discussion of our results.

\section{Research methodology}

We mobilize responses to an online questionnaire-based survey that we administered between 28 April and 5 May 2020 to professors and students from universities with 
economics and business administration profiles in 13 European countries, all but one members of the European Union. An initial invitation to complete the survey was addressed on April 28 2020, and a reminder was sent on May 3 2020. Given the difficulty in collecting data in this setting, we employ convenience sampling. In total, 114 academics and 248 students have responded to our invitation, which we regard as a large sample given the short period of administration. Given our affiliation with the Bucharest University of Economic Studies, Romania (ro. Academia de Studii Economice din Bucureşti, RomaniaASE), a good proportion of our respondents are from ASE. To ensure the completeness of answers, we have defined a series of validation conditions for the questions, to be checked before the submission of responses. Therefore, all our responses were complete in terms of questions addressed. The questions permitted the respondent to select a choice not to respond to some parts of the questions (and we report for each item analysed the number of respondents). Table no. 1 describes our sample.

Table no. 1. Demographic data on respondents

\begin{tabular}{|c|c|c|c|c|c|c|c|c|c|}
\hline \multirow{2}{*}{$\begin{array}{l}\text { Demographic } \\
\text { category }\end{array}$} & & \multicolumn{3}{|c|}{ Professors } & \multicolumn{3}{|c|}{ Students } & \multicolumn{2}{|c|}{ Total } \\
\hline & & Years & No. & $\%$ & Years & No. & $\%$ & No. & $\%$ \\
\hline \multirow[t]{3}{*}{ University } & ASE & & 37 & 32 & & 147 & 59 & 184 & 51 \\
\hline & $\begin{array}{l}\text { Other } \\
\text { Romanian }\end{array}$ & & 16 & 14 & & 39 & 16 & 55 & 15 \\
\hline & $\begin{array}{l}\text { Foreign } \\
\text { university }\end{array}$ & & 61 & 54 & & 62 & 25 & 123 & 34 \\
\hline \multirow[t]{3}{*}{ Country } & Romania & & 53 & 46 & & 186 & 75 & 239 & 66 \\
\hline & CEE & & 45 & 40 & & 60 & 24 & 105 & 29 \\
\hline & West & & 16 & 14 & & 2 & 1 & 18 & 5 \\
\hline \multirow{5}{*}{$\begin{array}{l}\text { Seniority } \\
\text { (years of } \\
\text { experience for } \\
\text { professors, } \\
\text { age for } \\
\text { students) }\end{array}$} & & $0-5$ & 7 & 6 & $18-21$ & 121 & 49 & & \\
\hline & & 6-10 & 14 & 12 & $22-25$ & 110 & 44 & & \\
\hline & & $11-20$ & 52 & 46 & $26-30$ & 7 & 3 & & \\
\hline & & $21-30$ & 36 & 32 & $>31$ & 10 & 4 & & \\
\hline & & $>30$ & 5 & 4 & & & & & \\
\hline Total & & & 114 & 100 & & 248 & 100 & 362 & 100 \\
\hline
\end{tabular}

More than half of the professors, and a quarter of the students, who responded to our survey are affiliated with universities from outside Romania. The number of respondents from countries outside Romania ranged between 1 to 29 per country for professors, top three countries being Poland (29), Greece (7) and the Czech Republic (6), and between 1 to 59 per country for students (most responses being received from Poland). We were thus able to conduct our cross-sectional analyses on groups of countries, distinguishing between Romania, other CEE countries (Bulgaria, Czech Republic, Estonia, Poland, Slovenia, and Russia) and Western Europe (France, Greece, Italy, Norway, Spain and the United Kingdom).

We have devised our research instrument in both Romanian and English. Surveys on separate links were produced for professors and students, but most questions were common, to facilitate a cross-sectional analysis on the type of respondents. The survey instrument comprised 16/15 questions for professors/students (including demographic questions) and was pre-tested on 4 academics and 2 students before large scale distribution. Minor rephrasing of the questions was undertaken as a result of the pre-testing. To check for nonresponse bias, we used two-tailed Mann-Whitney tests on the first and last 15 respondents 
in each category. No significant differences were obtained at the conventional level of $1 \%$. Cross-sectional analyses, Principal Component Analysis (PCA) and regression analyses were further used to statistically analyse the data. Cross-sectional analyses aimed to indicate the differences between sub-groups of respondents. We compared students vs. professors (reporting statistical significance as well), and responses from Romania vs. other CEE countries vs. Western Europe.

\section{Results}

\subsection{Online instructional and formative assessment methods}

We developed a list of online instructional methods from literature, including nine asynchronous and synchronous communication means (Kearns, 2012; Huang, et al., 2020). We investigate the extent to which these instructional methods were employed by respondents before, during, and are estimated (preferred) to be used after the pandemic (table no. 2).

Table no. 2. The use of online instructional methods

\begin{tabular}{|l|l|l|l|l|l|l|l|l|l|}
\hline \multirow{2}{*}{ Methods } & \multicolumn{3}{|c|}{ Before the pandemic } & \multicolumn{3}{|c|}{ During the pandemic } & \multicolumn{3}{|c|}{ After the pandemic } \\
\cline { 2 - 10 } & Mean & $\begin{array}{l}\text { Me- } \\
\text { dian }\end{array}$ & $\begin{array}{l}\text { St. } \\
\text { dev. }\end{array}$ & Mean & $\begin{array}{l}\text { Me- } \\
\text { dian }\end{array}$ & $\begin{array}{l}\text { St. } \\
\text { dev. }\end{array}$ & Mean & $\begin{array}{l}\text { Me- } \\
\text { dian }\end{array}$ & $\begin{array}{l}\text { St. } \\
\text { dev. }\end{array}$ \\
\hline Chat & 1.843 & 1 & 1.119 & $\begin{array}{l}2.942 \\
(* * *)\end{array}$ & 3 & 1.158 & $\begin{array}{l}2.552 \\
(* * *)\end{array}$ & 2 & 1.310 \\
\hline Forum & 1.964 & 2 & 1.166 & $\begin{array}{l}2.867 \\
(* * *)\end{array}$ & 3 & 1.234 & $\begin{array}{l}2.500 \\
(* * *)\end{array}$ & 2 & 1.324 \\
\hline $\begin{array}{l}\text { Uploading } \\
\text { materials }\end{array}$ & 3.818 & 4 & 1.148 & $\begin{array}{l}4.204 \\
(* * *)\end{array}$ & 5 & 1.030 & $\begin{array}{l}4.340 \\
(* *)\end{array}$ & 5 & 0.992 \\
\hline Emailing & 3.033 & 3 & 1.261 & 3.003 & 3 & 1.288 & $\begin{array}{l}3.354 \\
(* * *)\end{array}$ & 3 & 1.417 \\
\hline $\begin{array}{l}\text { Sharing } \\
\text { documents }\end{array}$ & 2.199 & 2 & 1.269 & $\begin{array}{l}2.489 \\
(* * *)\end{array}$ & 2 & 1.361 & $\begin{array}{l}2.959 \\
(* * *)\end{array}$ & 3 & 1.547 \\
\hline $\begin{array}{l}\text { Virtual } \\
\text { Whiteboard }\end{array}$ & 1.445 & 1 & 0.972 & $\begin{array}{l}2.099 \\
(* * *)\end{array}$ & 2 & 1.309 & $\begin{array}{l}2.525 \\
(* * *)\end{array}$ & 2 & 1.461 \\
\hline $\begin{array}{l}\text { Pre- } \\
\text { recorded } \\
\text { videos }\end{array}$ & 1.599 & 1 & 1.033 & $\begin{array}{l}2.254 \\
(* * *)\end{array}$ & 2 & 1.403 & $\begin{array}{l}3.055 \\
(* * *)\end{array}$ & 3 & 1.542 \\
\hline $\begin{array}{l}\text { Audio } \\
\text { conference }\end{array}$ & 1.754 & 1 & 1.341 & $\begin{array}{l}3.522 \\
(* * *)\end{array}$ & 4 & 1.465 & $\begin{array}{l}2.956 \\
(* * *)\end{array}$ & 3 & 1.481 \\
\hline $\begin{array}{l}\text { Video } \\
\text { conference }\end{array}$ & 1.657 & 1 & 1.234 & $\begin{array}{l}3.376 \\
(* * *)\end{array}$ & 4 & 1.486 & $\begin{array}{l}2.925 \\
(* * *)\end{array}$ & 3 & 1.484 \\
\hline \begin{tabular}{l} 
Others \\
\hline
\end{tabular} & 1.456 & 1 & 0.944 & $\begin{array}{l}1.649 \\
(* *)\end{array}$ & 1 & 1.180 & 1.660 & 1 & 1.245 \\
\hline Table no
\end{tabular}

Table no. 2 reports the use (assessed on a 5-point Likert scale, where $1=$ not at all; $5=$ very high extent) of 9 online instructional methods. $\mathrm{N}=362$ respondents (professors and students). The significant statistical differences between during vs. before, and after vs. during pandemic are reported (significant differences at 1,5 , and $10 \%$ are reported as ${ }^{* * *}, * *$, and ${ }^{*}$, respectively).

As seen from table no. 2, our respondents perceive that most online instructional methods were used to a small extent before the pandemic (median value of 1 for 6 of the listed methods). Only two methods were used to a medium to high extent (mean and median 
values higher than 2.5), i.e. emailing teaching materials (mean value 3.033) and uploading teaching materials in online platforms (mean value 3.818). These are means of interaction rather than online teaching, and are classified as asynchronous means (Craig, et al., 2012; Kearns, 2012), facilitating convenience in the process, but less live interaction. The switch to online interaction during the pandemic generates an increase in the use of all methods. The use of emails is the only means of interaction for which the increase is not statistically significant. Based on the mean values, the most employed means of interaction during the pandemic are: uploading materials on platforms (mean 4.204), audio conferencing (mean 3.522), video conferencing (3.376) and emailing materials (mean 3.003). It should be noticed that asynchronous communication remains important as well, but online teaching through synchronous methods (audio and video conferencing) becomes important during the pandemic.

Regarding the use of these methods after the pandemic, we notice that the extent of use is significantly higher for all means of interaction relative to before the pandemic crisis. Second, as expected, some means of interaction, clearly associated with online teaching (such as audio and video conferencing, the use of chat and forum) are expected to significantly decrease. However, respondents estimate that these methods will still remain used to a medium or high extent (mean values of 2.5 or higher). Surprisingly, some means of interaction are expected to be used to a higher extent after the pandemic crisis, some being related to online sharing of materials (online platforms, emails, Google drive), and others to online teaching (virtual whiteboards, pre-recorded videos). This is an indication of how the future education is expected to blend face-to-face, traditional means of interactions, with the online ones.

We next investigate the extent to which formative assessment methods were employed in education by respondents before, during and are estimated (preferred) to be used after the pandemic (table no. 3).

Table no. 3. The use of online formative assessment methods

\begin{tabular}{|c|c|c|c|c|c|c|c|c|c|}
\hline \multirow[t]{2}{*}{ Methods } & \multicolumn{3}{|c|}{ Before the pandemic } & \multicolumn{3}{|c|}{ During the pandemic } & \multicolumn{3}{|c|}{ After the pandemic } \\
\hline & Mean & $\begin{array}{l}\text { Me- } \\
\text { dian }\end{array}$ & $\begin{array}{l}\text { St. } \\
\text { dev. }\end{array}$ & Mean & $\begin{array}{l}\text { Me- } \\
\text { dian }\end{array}$ & $\begin{array}{l}\text { St. } \\
\text { dev. }\end{array}$ & Mean & $\begin{array}{l}\text { Me- } \\
\text { dian }\end{array}$ & St.dev. \\
\hline $\begin{array}{l}\text { Online } \\
\text { quizzes }\end{array}$ & 2.149 & 2 & 1.344 & $\begin{array}{l}3.387 \\
(* * *)\end{array}$ & 4 & 1.390 & $\begin{array}{l}2.862 \\
(* * *)\end{array}$ & 3 & 1.359 \\
\hline Homework & 3.414 & 4 & 1.323 & $\begin{array}{l}3.934 \\
(* * *)\end{array}$ & 4 & 1.134 & $\begin{array}{l}3.718 \\
(* *)\end{array}$ & 4 & 1.080 \\
\hline Projects & 3.260 & 3.5 & 1.384 & $\begin{array}{l}3.508 \\
(* *)\end{array}$ & 4 & 1.373 & 3.425 & 4 & 1.318 \\
\hline $\begin{array}{l}\text { Online } \\
\text { discussions }\end{array}$ & 1.851 & 1 & 1.252 & $\begin{array}{l}2.776 \\
(* * *)\end{array}$ & 3 & 1.353 & $\begin{array}{l}2.337 \\
(* * *)\end{array}$ & 2 & 1.334 \\
\hline $\begin{array}{l}\text { Audio } \\
\text { conference }\end{array}$ & 1.459 & 1 & 0.970 & $\begin{array}{l}2.445 \\
(* *)\end{array}$ & 2 & 1.433 & $\begin{array}{l}1.981 \\
(* * *)\end{array}$ & 1 & 1.226 \\
\hline $\begin{array}{l}\text { Video } \\
\text { conference }\end{array}$ & 1.392 & 1 & 0.903 & $\begin{array}{l}2.301 \\
(* * *)\end{array}$ & 2 & 1.403 & $\begin{array}{l}1.994 \\
(* * *)\end{array}$ & 1 & 1.243 \\
\hline Other & 1.227 & 1 & 0.717 & 1.392 & 1 & 0.971 & 1.370 & 1 & 0.933 \\
\hline
\end{tabular}


We note from table no. 3 that our respondents perceive as modest the use of online formative assessment before the pandemic, except for online homework and projects (mean values and median higher than 3). As expected, the use of online formative assessment significantly increases during the pandemic; homework and projects remained the most employed ones, immediately followed by online quizzes (the median value of all three is 4 ). The other three methods remain rarely used (mean values lower than 3). Similar to instructional methods, the pandemic is expected to result in an increase in the online assessment after the return to face-to-face activities. Even if the use of online methods is expected to significantly decrease after the pandemic, all mean values for the postpandemic period are higher than the values before the pandemic.

\subsection{Factors influencing online education}

We explore the factors influencing the online educational process, including the technological preparedness of people and universities for the rapid switch to online teaching. We asked respondents to estimate the importance of 12 factors (Borup and Evmenova, 2019) on online teaching. We conduct PCA with varimax rotation to narrow down the factors to more meaningful groups (the Kaiser-Meyer-Olkin measure of sampling adequacy is 0.776; the analysis passed Bartlett's test of sphericity). We retain four groups of factors that together explain $69.645 \%$ of the variation. We name each group based on the factors classified within (see table no. 4).

Table no. 4. Factors influencing online teaching

\begin{tabular}{|c|c|c|c|c|c|c|}
\hline \multirow{2}{*}{ Groups of factors } & \multirow{2}{*}{$\begin{array}{l}\text { Factor } \\
\text { loading }\end{array}$} & \multirow{2}{*}{ Mean } & \multirow{2}{*}{$\mathbf{N}$} & \multicolumn{3}{|c|}{ Cross-sectional analysis } \\
\hline & & & & Romania & CEE & West \\
\hline \multicolumn{7}{|c|}{ Institutional support } \\
\hline $\begin{array}{l}\text { University } \\
\text { adapted well to } \\
\text { online teaching }\end{array}$ & 0.841 & 4.066 & 362 & 4.000 & 4.173 & 4.316 \\
\hline Support received & 0.799 & 3.831 & 362 & 3.845 & 3.712 & 4.316 \\
\hline $\begin{array}{l}\text { Universities' } \\
\text { online platforms } \\
\text { are adequate }\end{array}$ & 0.754 & 3.751 & 362 & 3.728 & 3.865 & 3.421 \\
\hline $\begin{array}{l}\text { Courses are easily } \\
\text { transformable in } \\
\text { online format }\end{array}$ & 0.735 & 3.737 & 114 & 3.792 & 3.614 & 3.882 \\
\hline $\begin{array}{l}\text { Universities have } \\
\text { online platforms }\end{array}$ & 0.682 & 3.818 & 362 & 3.996 & 3.462 & 3.526 \\
\hline $\begin{array}{l}\text { Students are quick } \\
\text { to adapt to online }\end{array}$ & 0.648 & 4.193 & 114 & 4.151 & 4.182 & 4.353 \\
\hline \multicolumn{7}{|c|}{ Variance explained $29.170 \%$} \\
\hline \multicolumn{7}{|l|}{ Personal effort } \\
\hline $\begin{array}{l}\text { Time increased to } \\
\text { prepare classes }\end{array}$ & 0.860 & 3.884 & 362 & 3.787 & 4.048 & 4.211 \\
\hline $\begin{array}{l}\text { Time invested for } \\
\text { technological } \\
\text { preparedness }\end{array}$ & 0.682 & 3.097 & 362 & 3.105 & 2.952 & 3.789 \\
\hline
\end{tabular}




\begin{tabular}{|c|c|c|c|c|c|c|}
\hline \multicolumn{7}{|c|}{ Trust in the system } \\
\hline $\begin{array}{l}\text { The online system } \\
\text { is effective }\end{array}$ & 0.825 & 3.210 & 362 & 3.209 & 3.183 & 3.368 \\
\hline $\begin{array}{l}\text { Technological } \\
\text { preparedness }\end{array}$ & 0.809 & 3.873 & 362 & 3.833 & 3.971 & 3.842 \\
\hline \multicolumn{7}{|c|}{ Variance explained $16.162 \%$} \\
\hline \multicolumn{7}{|l|}{ Prior use } \\
\hline $\begin{array}{l}\text { Professors used } \\
\text { online more than } \\
\text { students }\end{array}$ & 0.839 & 3.254 & 114 & 3.377 & 3.318 & 2.706 \\
\hline $\begin{array}{l}\text { Prior online } \\
\text { teaching } \\
\text { experience }\end{array}$ & 0.550 & 2.740 & 362 & 2.849 & 2.462 & 2.895 \\
\hline \multicolumn{7}{|c|}{ Variance explained $10.371 \%$} \\
\hline \multicolumn{7}{|c|}{$\begin{array}{l}\text { Note: All items reflect factors influencing online teaching measured on a 5-point Likert }(1= \\
\text { strong disagreement, } 5=\text { strong agreement). The table reports the factor loading, mean response, } \\
\text { the number of respondents (some questions were intended only for professors), and cross- } \\
\text { sectional analysis on the geographical regions of respondents (Romania, Other CEE countries, } \\
\text { Western Europe). }\end{array}$} \\
\hline
\end{tabular}

The most important group of factors is named Institutional support and comprises six factors pertaining to universities. The most important factors are how quick universities adapted to the online format and the support received for online teaching. The mean values for each factor indicate that all factors are perceived to be important and very important for online teaching (mean values higher than 3). The cross-sectional analysis indicates that universities were quicker to adapt and provided more support in Western countries, relative to the ones in Romania and other CEE countries, even if, surprisingly, the existence of platforms with adequate functionalities is perceived to be lower, perhaps indicative of higher expectations from students in more advanced countries. The second factor is named Personal effort and regroups two factors: time allocated for online teaching and time invested (technologically) to adapt to online teaching. Both factors are perceived to be important (mean values between 3 and 4). The cross-sectional analysis shows that respondents from Western Europe put more personal effort into the online teaching than the rest of respondents. We name the third factor Trust in the system because it comprises two factors: the belief that online teaching is effective, and the technological preparedness, both being important (mean values between 3 and 4). The last group includes two factors reflecting the Prior use of online systems. It is noticeable that, for example, online systems had a low level of use (mean value 2.740), with comparable levels across the geographical locations studied.

\subsection{The effectiveness of the online educational process}

The quality of the educational process has been assessed in various forms in the literature, and is usually referred to as effectiveness (Chickering and Gamson, 1987; Gorsky and Blau, 2009), good interaction and learning outcomes (Bennett, Lockyer and Agostinho, 2018) or learner satisfaction (Englund, Olofsson and Pricee, 2017). We asked our respondents to indicate the perceived effectiveness of the various instructional and 
assessment methods, given that the quality (effectiveness) of the overall system depends upon the functionality and performance of each component.

Table no. 5. The impact of switching to online teaching

\begin{tabular}{|c|c|c|c|c|c|c|c|c|}
\hline \multirow{2}{*}{$\begin{array}{l}\text { Impact } \\
\text { measures }\end{array}$} & \multicolumn{3}{|c|}{ Total sample } & \multicolumn{2}{|c|}{ Respondents } & \multicolumn{3}{|c|}{ Geographical location } \\
\hline & Mean & St. dev. & $\mathbf{N}$ & Prof. & Stud. & Romania & $\overline{\text { CEE }}$ & West \\
\hline $\begin{array}{l}\text { Overall } \\
\text { impact }\end{array}$ & 3.092 & 0.709 & 362 & 3.000 & $\begin{array}{l}3.113 \\
\left(^{* *}\right)\end{array}$ & 3.112 & 3.059 & 3.011 \\
\hline $\begin{array}{l}\text { Effectiveness } \\
\text { of interaction } \\
\text { methods }\end{array}$ & 3.480 & 0.677 & 362 & 3.553 & 3.453 & 3.459 & 3.536 & 3.517 \\
\hline $\begin{array}{l}\text { Effectiveness } \\
\text { of formative } \\
\text { assessment } \\
\text { methods }\end{array}$ & 3.218 & 0.788 & 362 & 3.497 & $\begin{array}{l}3.096 \\
(* * *)\end{array}$ & 3.195 & 3.250 & 3.430 \\
\hline
\end{tabular}

Note: Table no. 5 reports the perceived influence of online teaching on the educational process (assessed on a 5-point Likert scale, where $1=$ not at all; $5=$ very large extent). $\mathrm{N}$ is the number of responses. We report mean and standard deviation for the entire sample. We report the results of cross-sectional analyses on professors versus students (significant differences at 1,5 , and $10 \%$ are reported as ${ }^{* * *}, * *$, and ${ }^{*}$, respectively), and on respondents from Romania vs. other CEE countries vs. Western Europe.

Results reported in table no. 5 indicate that overall the expected positive outcome of online teaching is achieved to a medium extent (mean value 3.092). However, results show that students perceive a significantly higher positive impact than professors, which is important given that students are an important stakeholder of the educational process. This impact is generated (untabulated results) by increased flexibility in time management, continuous feedback and taking more responsibility over the educational process (Grabinski, Kedzior and Krasodomska, 2015; D'Aquila, Wang and Mattia, 2019). However, untabulated results indicate that students interact less, which may trigger isolation feelings with negative consequences on learning (de Metz and Bezuidenhout, 2018). Results in table no. 5 also show that the perceived effectiveness of the online interaction methods and formative assessment is rather medium. We next investigate how the switch to the online teaching impacts the effectiveness of educational process, analyzed starting from the Chickering and Gamson's (1987) taxonomy (table no. 6):

Table no. 6. The effectiveness of online teaching

\begin{tabular}{|l|l|l|l|l|l|l|l|l|}
\hline \multirow{2}{*}{$\begin{array}{l}\text { Effectiveness } \\
\text { measures }\end{array}$} & \multicolumn{3}{|c|}{ Total sample } & \multicolumn{2}{c|}{ Respondents } & \multicolumn{3}{|l|}{ Geographical location } \\
\cline { 2 - 9 } & Mean & $\begin{array}{l}\text { St. } \\
\text { dev. }\end{array}$ & $\mathbf{N}$ & Prof. & Stud. & Romania & CEE & Western \\
\hline $\begin{array}{l}\text { Overall } \\
\text { effectiveness }\end{array}$ & 1.848 & 0.457 & 362 & 1.754 & $\begin{array}{l}1.891 \\
(* * *)\end{array}$ & 1.838 & 1.885 & 1.741 \\
\hline $\begin{array}{l}\text { Student-teacher } \\
\text { communication }\end{array}$ & 1.669 & 0.737 & 362 & 1.588 & $\begin{array}{l}1.706 \\
(* * *)\end{array}$ & 1.678 & 1.625 & 1.789 \\
\hline $\begin{array}{l}\text { Communication } \\
\text { and cooperation } \\
\text { between students }\end{array}$ & 1.742 & 0.713 & 248 & & 1.742 & 1.710 & 1.817 & 2.500 \\
\hline Active learning & 1.751 & 0.740 & 362 & 1.711 & 1.770 & 1.715 & 1.856 & 1.632 \\
\hline $\begin{array}{l}\text { Immediate } \\
\text { feedback }\end{array}$ & 1.840 & 0.700 & 362 & 1.904 & $\begin{array}{l}1.810 \\
\left.*^{* *}\right)\end{array}$ & 1.837 & 1.846 & 1.842 \\
\hline
\end{tabular}




\begin{tabular}{|l|l|l|l|l|l|l|l|l|}
\hline \multirow{2}{*}{$\begin{array}{l}\text { Effectiveness } \\
\text { measures }\end{array}$} & \multicolumn{3}{|c|}{ Total sample } & \multicolumn{3}{c|}{ Respondents } & \multicolumn{3}{|c|}{ Geographical location } \\
\cline { 2 - 8 } & Mean & $\begin{array}{l}\text { St. } \\
\text { dev. }\end{array}$ & N & Prof. & Stud. & Romania & CEE & Western \\
\hline $\begin{array}{l}\text { Time spent } \\
\text { preparing for a } \\
\text { course }\end{array}$ & 2.302 & 0.796 & 248 & & 2.302 & 2.263 & 2.450 & 1.500 \\
\hline $\begin{array}{l}\text { Expectations } \\
\text { from students }\end{array}$ & 2.039 & 0.765 & 362 & 1.877 & $\begin{array}{l}2.113 \\
\left({ }^{* * *}\right)\end{array}$ & 2.013 & 2.106 & 2.000 \\
\hline $\begin{array}{l}\text { Respecting the } \\
\text { differences } \\
\text { between students }\end{array}$ & 1.762 & 0.639 & 362 & 1.693 & $\begin{array}{l}1.794 \\
\left({ }^{* *}\right)\end{array}$ & 1.778 & 1.779 & 1.474 \\
\hline
\end{tabular}

Note: Table no. 6 reports the perceived effectiveness of online teaching (assessed on a 3-point Likert scale, where $1=$ decreased; $2=$ maintained; $3=$ increased). $\mathrm{N}$ is the number of responses (two impact measures were assessed only by students). We report the results of cross-sectional analyses on professors versus students (significant differences at 1,5 , and $10 \%$ are reported as ${ }^{* * *}$, ${ }^{* *}$, and ${ }^{*}$, respectively), and on respondents from Romania vs. other CEE countries vs. Western Europe.

Our analysis reflects the impact of switching to online teaching during the pandemic, in terms of decreased, maintained, or increased effectiveness (3-point Likert scale). Only two of the seven effectiveness measures have mean values higher than 2 (which means at least maintaining the level of effectiveness), indicating that the online teaching is not perceived to maintain various levels of quality in the educational process. The measures maintained include expectations from students and students' time on a course. On the other hand, communication between students, between students and professors, immediate feedback, active learning and respecting differences between students in terms of skills and learning styles are perceived to have decreased with online teaching. The overall effectiveness score, which has a mean value lower than 2 (mean value 1.848) captures the perceived decrease in effectiveness. Students' perception of effectiveness is slightly higher than that of professors, but still lower than in the case of traditional teaching.

We next investigate the factors associated with the outcomes of the educational process. For each measure of outcome, i.e. impact and effectiveness, we analyze the association with the perceived effectiveness of methods, their use, and the factors influencing the educational process. Results are reported in table no. 7.

Table no. 7. Factors associated with the impact and effectiveness of online teaching

\begin{tabular}{|l|l|l|l|l|}
\hline \multirow{2}{*}{ Factors } & \multicolumn{2}{c|}{ Impact } & \multicolumn{2}{c|}{ Effectiveness } \\
\cline { 2 - 5 } & Coefficient & t-stat & Coefficient & t-stat \\
\hline Institutional support & $0.193^{* * *}$ & 3.862 & $0.145^{* * *}$ & 2.866 \\
\hline Personal effort & 0.040 & 0.436 & 0.030 & 0.571 \\
\hline Trust in the system & $0.323^{* * *}$ & 6.381 & $0.297^{* * *}$ & 5.812 \\
\hline Prior use instructional & 0.004 & 0.937 & 0.039 & 0.801 \\
\hline $\begin{array}{l}\text { Effectiveness of } \\
\text { methods }\end{array}$ & $0.179^{* * *}$ & 3.116 & $0.177^{* * *}$ & 3.028 \\
\hline Use of instructional methods & -0.089 & -1.555 & 0.038 & 0.655 \\
\hline $\begin{array}{l}\text { Effectiveness of assessment } \\
\text { methods }\end{array}$ & $0.106^{* *}$ & 1.823 & 0.015 & 0.257 \\
\hline Use of assessment methods & 0.046 & 0.792 & 0.057 & 0.965 \\
\hline
\end{tabular}




\begin{tabular}{|l|l|l|l|l|}
\hline \multirow{2}{*}{ Factors } & \multicolumn{2}{c|}{ Impact } & \multicolumn{2}{c|}{ Effectiveness } \\
\cline { 2 - 5 } & Coefficient & t-stat & Coefficient & t-stat \\
\hline Adjusted R ${ }^{2}$ & 0.247 & & 0.221 & \\
\hline Probability & 0.000 & & 0.000 & \\
\hline F statistic & 10.785 & & 9.530 & \\
\hline No. observations & 359 & & 361 & \\
\hline
\end{tabular}

Table no. 7 reports that two of the factors influencing the educational process are positively associated with the impact and effectiveness of online teaching, i.e. institutional support and trust in the system. Institutional support regroups the university's technological readiness (existing platforms, support offered) and responsiveness, and the students' readiness to use online systems. Moreover, trust in the system is important, which is actually a personal reflection on the opportunity, readiness and impact of online education. We corroborate prior findings that the personal attitudes of professors (Bhati, et al., 2009) and of students (de Metz and Bezuidenhout, 2018) are critical in successfully implementing online education, but we also show how this is more important than the personal effort or prior use of online methods. Moreover, neither the impact nor the effectiveness of online teaching are influenced by the extent of use of instructional and formative assessment methods, but they are associated with their perceived effectiveness. This is a clear indication that for all respondents, professors and students, the effectiveness of assessment (in this case, formative, continuous assessment) is a crucial part of the educational process.

\section{Conclusions}

The current COVID-19 pandemic forced an abrupt switch to online teaching in universities around the world. While this might not be a good moment to evaluate the effectiveness of online education (Greene, 2020), the impact of this event is important for universities, students and employers (QS, 2020).

Relative to online educational practices, we find that the interaction and assessment methods employed indicate a rather passive delivery and reduced interaction (the only method used to a high extent is sending class materials, online and video conferencing being employed to a medium to high extent). The repertoire of interaction and assessment methods remains quite limited relative to what is usually subsumed into online learning tools (Craig, et al., 2012; Kearns, 2012), since, for example, few respondents indicated the use of pre-recorded videos, virtual whiteboards, business games and online simulations. On the other hand, even if online interaction and assessment methods are employed only to a medium to high degree (and not extensively) during the pandemic, an increased use relative to the situation before the crisis is statistically significant for almost all the methods investigated. Therefore, we argue that the pandemic forced the stakeholders of the academic educational process to quickly accept some online tools, which will continue to be used to some extent once the educational system returns to a traditional format. However, we emphasize that the trust in the effectiveness in these tools is only medium, which may impact their future use as well. This level of trust might result from the quick turn and forced embracement of online tools, which may result in restricted use and limited positive outcomes. Overall, it is obvious that the current online experience will impact the future of education, and future research is needed to understand both positive and negative consequences of this abrupt change. 
Second, we explore the barriers to and facilitators of online education. We find that the support received, the time invested, the existence and facilities of online platforms and technological readiness acted as facilitators rather than barriers in the process. However, the switch to online teaching was influenced by many more other factors, and future research might investigate in more depth the barriers and facilitators of this change. In this case, interviews and focus groups might offer more in-depth data about personal experiences.

Third, we investigate the outcomes of the educational process. The switch to online teaching has an overall moderate positive perceived impact, and, the overall effectiveness of the online educational experience is perceived to be lower than in the case of face-to-face teaching. The importance of interaction and active learning in online teaching in the online context is not easy to ensure. Our results indicate that institutional support, trust in the online system, and the perceived effectiveness of formative assessment are positively associated with the impact and effectiveness of online education. We therefore conclude that an effective online system is not only the result of an assembly of properly tailored instructional and assessment tools, but, more importantly, of the trust of its users, which stems from technological readiness and the overall confidence that the system is functioning towards the intended objectives.

\section{References}

Albăstroiu, I., Felea M. and Vasiliu, C., 2014. Geographic Information System - modern teaching method in business administration. Amfiteatru Economic, 16(37), pp.770-783.

Bangert, A., 2006. The development of an instrument for assessing online teaching effectiveness. Journal of Educational Computing Research, 35(3), pp.227-244.

Bao, W., 2020. COVID-19 and online teaching in higher education: A case study of Peking University. Human Behavior and Emerging Technologies, 2(2), pp.113-115.

Baran, E., Correia, A.P. and Thompson, A.D., 2013. Tracing successful online teaching in higher education: voices of exemplary online teachers. Teachers College Record, 115(3), pp.1-41.

Bennett, S., Lockyer, L. and Agostinho, S., 2018. Towards sustainable technologyenhanced innovation in higher education: Advancing learning design by understanding and supporting teacher design practice. British Journal of Educational Technology, 49(6), pp.1014-1026.

Bhati, N., Mercer, S., Rankin, K. and Thomas B., 2009. Barriers and facilitators to the adoption of tools for online pedagogy. International Journal of Pedagogies and Learning, 5(3), pp.5-19.

Bonk, C.J., and Graham, C.R. 2006. Handbook of blended learning: global perspectives, local designs. San Francisco, CA: Pfeiffer Publishing.

Borup, J. and Evmenova, A.S., 2019. The effectiveness of professional development in overcoming obstacles to effective online instruction in a college of education. Online Learning, 23(2), pp.1-20.

Boyle, S.L.T., Kolosh, K., L'Allier, J., and Lambrecht J. 2003. Thompson NETg's blendedlearning model: The next generation of corporate and school-based learning. The Delta Pi Epsilon, 45(3), pp.145-161. 
Burgess, S. and Sievertsen, H., 2020. Schools, skills, and learning: The impact of COVID19 on education. [online] VOXEU. Available at: <https://voxeu.org/article/impactcovid-19-education> [Accessed 5 May 2020].

Burquel, N. and Busch, A., 2020. Lessons for international higher education post COVID19. [online] University World News. Available at: <https://www.universityworldnews.com/post.php?story=2020042408501836> [Accessed 5 May 2020].

Chickering, A.W. and Gamson, Z.F., 1987. Seven principles for good practice in undergraduate education. American Association for Higher Education Bulletin, 39(7), pp.3-7.

Connolly, T.M., MacArthur, E., Stansfiled, M. and McLesslan, E., 2007. A quasiexperimental study of three online learning courses in computing. Computers \& Education, 49, pp.345-359.

Craig, A., Coldwell-Neilson, J., Goold, A. and Beekhuyzen, J., 2012. A review of e-learning technologies. Opportunities for Teaching and Learning. In: CSEDU 2012, Proceedings of the $4^{\text {th }}$ International Conference on Computer Supported Education. Porto, Portugal, 2012: INSTICC.

D’Aquila, J.M., Wang, D. and Mattia, A., 2019. Are instructor generated YouTube videos effective in accounting classes? A study of student performance, engagement, motivation, and perception. Journal of Accounting Education, 47, pp.63-74.

De Metz, N. and Bezuidenhout, A., 2018. An importance-competence analysis of the roles and competencies of e-tutors at an open distance learning institution. Australasian Journal of Educational Technology, 34(5), pp.27-43.

Dennis, M. 2020. How will higher education have changed after COVID-19? [online] University World News. Available at <https://www.universityworldnews.com/ post.php?story=20200324065639773> [Accessed 5 May 2020].

Dixson, M.D., 2010. Creating effective student engagement in online courses: What do students find engaging? Journal of the Scholarship of Teaching and Learning, 10(2), pp.1-13.

Englund, C., Olofsson, A.D. and Price, L., 2017. Teaching with technology in higher education: understanding conceptual change and development in practice. Higher Education Research \& Development, 36(1), pp.73-87.

European Commission, 2020. COVID-19 is reviving the need to explore online teaching and learning opportunities. [online] EPALE - Electronic Platform for Adult Learning in Europe Blog. Available at: <https://epale.ec.europa.eu/en/blog/covid-19-reviving-needexplore-online-teaching-and-learning-opportunities> [Accessed 10 May 2020].

Gaytan, J. and McEwen, B.C., 2007. Effective online instructional and assessment strategies. The American Journal of Distance Education, 21(3), pp.117-132.

Gorsky, P. and Blau, I., 2009. Online teaching effectiveness: a tale of two instructors. The International Review of Research in Open and Distributed Learning, 10(3), pp.1-27.

Grabinski, K., Kedzior, M. and Krasodomska, J., 2015. Blended learning in tertiary accounting education in the CEE region - A Polish perspective. Accounting and Management Information Systems, 14(2), pp.378-397. 
Greene, J., 2020. How (not) to evaluate teaching during a pandemic. The Chronicle of Higher Education. [online] Available at: <https://www.chronicle.com/article/How-Notto-Evaluate-Teaching/248434> [Accessed 10 May 2020].

Huang, R.H., Liu, D.J., Tlili, A., Yang, J.F., Wang, H.H., et al., 2020. Handbook on Facilitating Flexible Lerning during Educational Disruption: The Chinese Experience in Maintaining Undisrupted Learning in COVID-19 Outbreak. Beijing: Smart Learning Institute of Beijing Normal University.

Janse van Rensburg, E.S., 2018. Effective online teaching and learning practices for undergraduate health sciences students: An integrative review. International Journal of Africa Nursing Sciences, 9, pp.73-80.

Johnson, S.D. and Aragon, S.R., 2003. An instructional strategy framework for online learning environments. New Directions for Adult and Continuing Education, 100, pp.31-43.

Jones, S., 2020. Covid-19 is our best chance to change universities for good. [online] The Guardian. Available at <https:/www.theguardian.com/education/2020/mar/31/covid19-is-our-best-chance-to-change-universities-for-good> [Accessed 5 May 2020].

Kauppi, S., Muukkonen, H., Suorsa, T. and Takala, M., 2020. I still miss human contact, but this is more flexible - Paradoxes in virtual learning interaction and multidisciplinary collaboration. British Journal of Educational Technology, 0(0), pp.1-16.

Kearns, L.R., 2012. Student assessment in online learning: Challenges and effective practices. MERLOT Journal of Online Learning and Teaching, 8(3), pp.198-208.

Liang, X. and Creasy, K., 2004. Classroom assessment in Web-based instructional environment: Instructors' experience. Practical Assessment, Research \& Evaluation, 9(7), pp.1-9.

Lim, M., 2020. Educating despite the Covid-19 outbreak: lessons from Singapore. [online] Times Higher Education. Available at: <https://www.timeshighereducation. com/blog/educating-despite-covid-19-outbreak-lessons-singapore\#survey-answer> [Accessed 5 May 2020].

Maki, R.H. and Maki, W.S., 2007. Online Courses. In: F.T. Durso, ed., 2007, Handbook of applied cognition. New York: Wiley \& Sons, Ltd., pp.527-552.

Martin, F., Wang, C. and Sadaf, A., 2018. Student perception of helpfulness of facilitation strategies that enhance instructor presence, connectedness, engagement and learning in online courses. The Internet and Higher Education, 37, pp.52-65.

McCarthy, M., Kusaila, M. and Grasso, L., 2019. Intermediate accounting and auditing: Does course delivery mode impact student performance? Journal of Accounting Education, 46, pp.26-42.

Myring, M., Bott, J.P. and Edwards, R., 2014. New approaches to online accounting education. CPA Journal, 84, pp.66-71.

OECD, 2013. Assessment of higher education learning outcomes. AHELO Feasibility Study Report. [pdf] Washington: OECD. Available at: <https://www.oecd.org/ education/ skills-beyond-school/AHELOFSReportVolume3.pdf> [Accessed 4 May 2020].

OECD 2020. A framework to guide an education response to the COVID-19 Pandemic of 2020. [pdf] Available at: <https://globaled.gse.harvard.edu/files/geii/files/ framework_guide_v2.pdf $>$ [Accessed 4 May 2020]. 
Onete, B., Pleșea, D., Teodorescu, I. and Cîrstea, A, 2014. Evolutions and Opportunities of Business Education in the Context of Educational Reform From the Digital Age. Amfiteatru Economic, 16(37), pp.746-758.

Pelgrum, W.J., 2001. Obstacles to the Integration of Ict in Education: Results From a Worldwide Educational Assessment. Computers \& Education, 37(2), pp.163-178.

QS, 2020. The impact of the coronavirus on global higher education. [pdf] London: QS, Available at: <https://www.qs.com/portfolio-items/the-impact-of-the-coronavirus-onglobal-higher-education/> [Accessed 9 May 2020].

Robles, M. and Braathen, S., 2002. Online assessment techniques. The Delta Pi Epsilon Journal, 44(1), pp.39-49.

Shi, M., 2019. The effects of class size and instructional technology on student learning performance. The International Journal of Management Education, 17, pp.130-138.

Stanciu, V. and Gheorghe, M., 2017. An exploration of the accounting profession - The stream of mobile devices. Accounting and Management Information Systems, 13(3), pp.369-385.

Stanciu, V. and Tinca, A., 2014. A critical look on the student's Internet use - an empirical study. Accounting and Management Information Systems, 13(4), pp.739-754.

Teo, T., 2011. Factors influencing teachers' intention to use technology: Model development and test. Computers \& Education, 57(4), pp.2432-2440.

Warren, J., Rixner, S., Greiner, J. and Wong, S., 2014. Facilitating human interaction in an online programming course. SIGCSE 2014 - Proceedings of the $45^{\text {th }}$ ACM Technical Symposium on Computer Science Education. Atlanta Georgia USA, March 2014. New York: Association for Computing Machinery. 